\title{
Measuring the Effects of Online-to-Offline Marketing
}

\author{
I-Ping Chiang \\ National Taipei University \\ E-Mail: ipchiang@mail.ntpu.edu.tw \\ Chia-Yi Lin \\ National Taipei University \\ E-Mail: jason05218073@hotmail.com \\ Chih-Hui Huang \\ National Taipei University \\ E-Mail: ful67485@gmail.com
}

\begin{abstract}
Due to the competitiveness of the e-commerce environment and the emerging usage of mobile devices, companies have found a new e-marketing strategy, that is, online-to-offline (O2O) marketing, to integrate both channels more efficiently. The rapid rise of the $\mathrm{O} 2 \mathrm{O}$ market in recent years has changed the way people consume and become an important issue. However, there are still very few studies focusing on $\mathrm{O} 2 \mathrm{O}$ marketing issues. Hence, the purpose of this study is to develop an analytic model to explore how consumers adopt $\mathrm{O} 2 \mathrm{O}$ commerce models.

In this study, we collect 1,267 samples of valid Taiwan-based internet users who intended to adopt multi-channel retailing, using a web survey of consumers through InsightXplorer's CyberPanel. We use EFA and CFA to confirm search factors (information availability, search convenience, enjoyment, media richness and tangibility) and purchase factors (service quality, price and promotion, purchase convenience, risk perception, immediacy and product quantity) in keeping with past research. We also conduct a multinomial logit model to analyze the relationships among search factors, purchase factors, and adopting multi-channel purchasing behavior. The results indicate that the main reason consumers choose to purchase through physical channels is that they could provide better sales service quality and have a lower shopping risk, however, if consumers care about prices and promotions, they tend to
\end{abstract}


lean towards the Mobile path. At the close of this paper, in-depth discussions and conclusions are provided to inform further research and future practices.

Keywords: Online-to-offline (O2O), E-commerce, E-marketing, Internet marketing, Omni-channel retailing.

\section{INTRODUCTION}

Nowadays, the rapid development of the Internet and mobile technologies has driven e-business to make a breakthrough. More and more traditional retailers are developing virtual online channels (Chen, Wang, \& Jiang, 2016). Since the rise in electronic and mobile commerce in recent years, consumers tend to adopt multiple channels for researching and purchasing products and services. Nielsen (2014) reports that $96 \%$ of Web users in Taiwan shop online, while among them, those who search for and purchase products through mobile devices (smart phones and tablets) has increased from $24 \%$ to $32 \%$. eMarketer (2018) mentions that mobile phones with better location tracking and identity graphs are better tools for judging the full impact of online media. These $\mathrm{O} 2 \mathrm{O}$ capabilities have made advertisers able to refine goals, change creative activities, and rethink their media mixes. Demand for $\mathrm{O} 2 \mathrm{O}$ measurements has increased in most industries over these past 2 years.

Consumers have enhanced their cross-channel shopping behavior by applying more functions through mobile devices. According to TNS (2013), 24\% of people used a smartphone or tablet to search for information on products at home, $21 \%$ used mobile devices to compare prices in stores, $16 \%$ viewed product information, $16 \%$ used coupons, and 15\% used mobile commerce to purchase products. ComScore (2013) investigates 3,000 consumers, 44\% of which report that they prefer to patronize stores that provide online ordering and in-store pickup. Stores that adopt the online-to-offline $(\mathrm{O} 2 \mathrm{O})$ marketing model attract consumers to visit the store and purchase products. Therefore, understanding the $\mathrm{O} 2 \mathrm{O}$ marketing model is crucial. In this study, we introduce a model for finding how to efficiently mix marketing resources on offline and online channels to create a successful O2O marketing strategy. Based on the description above, the research purposes of this study are to (a) draw conclusions from past literature to establish $\mathrm{O} 2 \mathrm{O}$ adoption behaviors and factors to confirm these factors through factor analysis, (b) establish a measurement model of $\mathrm{O} 2 \mathrm{O}$ adoption behaviors and factors, and then explore the relationship between $\mathrm{O} 2 \mathrm{O}$ adoption behavior and factors, (c) explore the relationship between the transfer behavior of each channel and the factors of transfer consideration, and (d) propose references and suggestions for researchers and marketing personnel related to $\mathrm{O} 2 \mathrm{O}$ in the future. 


\section{THEORETICAL BACKGROUND}

\section{Online-to-Offline Marketing}

The $\mathrm{O} 2 \mathrm{O}$ marketing model is also known as the online and offline integration model. Alex Rampell, the chief executive officer and founder of TrialPay, states that the key to $\mathrm{O} 2 \mathrm{O}$ marketing is locating consumers online and bringing them into realworld stores (TechCrunch, 2010). The model is a combination of a payment model and foot traffic generator for merchants (and a discovery mechanism for consumers) that enables offline purchasing. For example, an online channel can't provide an actual restaurant experience and is only used to trade goods unilaterally. In contrast, an offline channel can't provide people with information on store locations or promotions. Therefore, a complementary model that companies to attract additional consumers to physical stores is necessary. The Online Economy (2012) indicates that since the increase of social networking sites and location-based services, consumers now obtain preferential information on products through both channels and then purchase products from physical stores. Business Insider (2011) surveys four available methods for O2O models: the traditional online store, location-based services, social commerce, and group purchasing. In addition, the $\mathrm{O} 2 \mathrm{O}$ marketing model has become a critical topic in channel integration (Business Insider, 2011). Consumers consider various factors for adopting the most appropriate channel to execute their transactions. For instance, if consumers seek to find information quickly, they will select online stores, often using mobiles device to do so. In contrast, if consumers want to try on a product, they will visit a physical store. Therefore, we speculate that understanding the factors leading to consumers' searching and purchasing, as well as those of subsequent behaviors is crucial. Moreover, marketers must mix their marketing resources on offline and online/mobile channels to effectively and efficiently attract target consumers.

\section{Online-To-Offline Adoption Factors for the Search Process}

\section{Information Availability}

Verhoef, Neslin, \& Vroomen (2007) consider the availability of product information and find that the amount of useful information influences consumers when choosing the most appropriate channel for searching. Wolfinbarger and Gilly (2001) reveal that information availability is a reason for consumers to use online channels for searching goods. Scholars have stated that the Internet provides the most efficient means for consumers to obtain product information. If consumers can easily receive information and compare prices by using one channel, they tend to search and purchase using that same channel (Noble, Griffith \& Weinberger, 2005). Thus, we propose the 
following hypothesis:

H1: Consumers who care about information availability are more likely to search for goods through an online channel.

\section{Search Convenience}

Many consumers will select channels that can quickly provide product information (Verhoef et al., 2007). Gupta, Su, and Walter (2004) argue that online channels could offer quicker outcomes in searching for product information. In addition, Bang, Lee, Han, Hwang and Ahn (2013) state that mobile devices enable one to search for information anytime and anywhere. Several studies have also indicated that searching convenience affects channel choice for consumers (Kacen, Hess, \& Kevin, 2013; Schröder \& Zaharia, 2008; Verhoef, Neslin, \& Vroomen, 2007). Thus, we propose the following hypothesis:

H2: Consumers who care about search convenience are more likely to search for goods through an online channel.

\section{Search Enjoyment}

Forsythe, Liu, Shannon, and Gardner (2006) determine that many consumers are highly concerned about enjoying the search process. Consumers require hedonic elements from the shopping experience (Schröder \& Zaharia, 2008). Several scholars have determined that such consumers use channels that provide enjoyable shopping experiences. Consumers who prefer to search for goods in stores do so because they experience more shopping pleasure and have more face-to-face interactions with sales staff than they do online (Jones, 1999; Rohm \& Swaminathan, 2004; Konuş, Verhoef, \& Neslin, 2008; Levin, Levin, \& Weller, 2005; Schröder \& Zaharia, 2008). Thus, we propose the following hypothesis:

H3: Consumers who care about search enjoyment are more likely to search for goods through an offline channel.

\section{Tangibility}

Shin (2007) indicates that consumers who did not purchase goods through an online channel behave in such a way because they cannot assess the actual quality of products while purchasing, remaining uncertain about the goods. Consumers tend to examine physical products at stores to reduce uncertainty (Jiang \& Balasubramanian, 2014). In addition, numerous studies have indicated that tangibility is crucial in $\mathrm{O} 2 \mathrm{O}$ marketing (Kacen et al., 2013; Levin et al., 2005; Yu, Niehm, \& Russell, 2011). Thus, we propose the following hypothesis: 
H4: Consumers who care about product tangibility are more likely to search for goods through an offline channel.

\section{Media Richness}

Media richness enables marketing channels to convey information to consumers and help them make decisions (Maity \& Dass, 2014). Relevant literature has reported that media richness affects the way people search for information. Brunelle (2009) indicates that consumers who have been affected by media richness changed their intentions and adopted e-commerce to search for information. Maity and Dass (2014) state that offline, online, and mobile channels provide different degrees of media richness. If consumers want to acquire in-depth information or timely feedback, they could ask a salesperson in a physical store. As such, we speculate that media richness affects the search channel choice for consumers. Thus, we propose the following hypothesis:

H5: Consumers who care about media richness are more likely to search for goods through an offline channel.

\section{Online-To-Offline Adoption Factors for the Purchasing Process}

\section{Price and Promotion}

Several scholars have indicated that price and promotion influence channel choice for consumers in the purchasing process. Bakos (1997) indicates that price is a critical factor influencing the choice of a channel for purchasing goods. For instance, consumers believe that they can find inexpensive products through online channels and thus use these channels to search for prices and promotions. Numerous studies have also revealed that consumers search for products by using offline channels; however, these same customers use online stores for purchasing these products when the prices through offline channels are exceedingly high (Crespo \& Del Bosque, 2010; Kacen et al., 2013; Konuş et al., 2008; Maity \& Dass, 2014; Schröder \& Zaharia, 2008; Van Baal \& Dach, 2005; Verhoef et al., 2007). Therefore, we assume that prices and promotions are crucial factors in the $\mathrm{O} 2 \mathrm{O}$ marketing model. Thus, we propose the following hypothesis:

H6: Consumers who care about prices and promotions are more likely to make purchases through an online channel.

\section{Product Variety}


Keeney (1999) argues that if stores provide more product variety, more potential consumers could purchase products there. Verhoef et al. (2007) indicate that if stores provide assorted products (e.g., popular or new products), consumers might change their purchase channel in response. In addition, numerous studies have shown that eretailing can provide a wide assortment of products and abundant information. These benefits are often discussed in the context of superior e-merchandizing motivating people to shop online (Clemes, Gan, \& Zhang, 2013; Evanschitzky, Iyer, Hesse, \& Ahlert, 2004), Thus, we propose the following hypothesis:

H7: Consumers who care about product variety are more likely to make purchases through an online channel.

\section{Purchase Convenience}

Verhoef et al. (2007) determine that many consumers prefer to purchase goods through channels which provide highly efficient purchasing processes. In addition, Schröder and Zaharia (2008) indicate that convenience orientation characterizes consumers who regard shopping as a rational problem-solving process. Acquiring a sought-after product with minimal investment in time and physical or mental effort is crucial to consumers. Gupta et al. (2004) indicates that when consumers want to search for and purchase products, they consider whether considerable effort or time will be taken when purchasing those products. For instance, if consumers search for products at a physical store, they expend much time and effort. In addition, if consumers can't find an appropriate product (when prices are exceedingly high or the products do not have favorable attributes), they must expend additional time and effort searching. Lee, Han, Hwang, and Ahn (2013) state that the advantage of mobile devices is that information can be searched for and products can be purchased anytime and anywhere. Several studies have shown that purchase convenience is a crucial factor in the purchasing process (Chocarro, Cortiñas, \& Villanueva, 2013; Kwon \& Jain, 2009; Schröder \& Zaharia, 2008). Thus, we propose the following hypothesis:

H8: Consumers who care about purchase convenience are more likely to make purchases through an online channel.

\section{Online Purchase Risk}

Cox and Rich (1964) define risk perception as the perception of uncertainty in the purchasing process. Taylor (1974) indicates that consumers change their purchase channels because of the different risks that influence their decisions; he also states that product performance risk and security risk might affect purchase decisions. Featherman and Pavlou (2003) indicate that consumers could be concerned about the potential loss 
of control over personal information, for example, consumers seldom purchase from online stores that use their personal information without permission. Several studies have indicated that online purchase risk affects the channel choice of consumers (Clemes et al., 2013; Liu \& Forsythe, 2011; Schröder \& Zaharia, 2008). Thus, we propose the following hypothesis:

H9: Consumers who care about online purchase risk are more likely to make purchases through an offline channel.

\section{Sales Service Quality}

Numerous studies have indicated that if stores provide superior sales service quality, then consumers might change their final purchase channel choice. Parasuraman, Zeithaml, and Berry (1988) indicate that sales service quality includes tangibility, reliability, responsiveness, assurance, and empathy. Parasuraman, Zeithaml, and Malhotra (2005) discuss e-sales service quality, asserting the quality difference between offline and online, and propose that including e-quality could offer various means of returns or increase the availability of items for delivery within a suitable time frame. In addition, Kacen et al. (2013) indicates that consumers who care about sales service quality tend to purchase from offline stores. Numerous studies have indicated that sales service quality is a critical factor in the purchase process (Verhoef, Neslin, \& Vroomen, 2007; Yu, Niehm \& Russell, 2011). Thus, we propose the following hypothesis:

H10: Consumers who care about sales service quality are more likely to make purchases through an offline channel.

\section{Immediate Possession}

Several studies suggest that direct marketers can reduce consumer resistance to catalogues or making Internet purchases by reducing the delivery time. Thus, consumers might decide to use offline stores rather than online stores to gain immediate possession of products (Balasubramanian, 1998; Rohm \& Swaminathan, 2004). Alba et al. (1997) states that brick and mortar retailers provide instantaneous possession of products, whereas purchasing through online retailers incurs a time delay. Numerous studies have indicated that if consumers can receive products immediately, they will change the purchase channel to do so (Chiang, Zhang, \& Zhou, 2006; Kacen et al., 2013; Noble, Griffith \& Weinberger, 2005; Rohm \& Swaminathan, 2004). Thus, we propose the following hypothesis:

H11: Consumers who care about immediate possession are more likely to make purchases through an offline channel. 
Early study results have discovered many consumers' cross-channel behaviors (such as offline channel search to online purchase or mobile search to offline purchase). To complete the transaction (Farag, Schwanen, Dijst, \& Faber, 2007; Schröder \& Zaharia, 2008; Verhoef et al, 2007), Pookulangara, Hawley, and Xiao (2011) indicate that the consumers consider price, promotions, purchase time and purchase risk, leading to cross-channel behavior. Gupta et al. (2004) also indicates several factors that influence consumers to change purchase channels while searching for products in physical stores, such as the time for online channels to deliver, online product evaluations, and delivery or payment risks of online channels. Thus, we propose the following hypotheses:

H12: Sales service quality influences consumers searching online to cross over to purchase offline.

H13: Product variety influences consumers searching offline to cross over to purchasing online.

H14: Purchase convenience influences consumers searching offline to cross over to make purchases via mobile.

H15: Online purchase risks influence consumers searching online and on mobile devices to cross over to purchasing offline.

H16: Price and promotional information influences consumers searching offline to cross over to purchasing online.

H17: Immediate possession influences consumers searching online to cross over to purchasing offline.

\section{RESEARCH METHODOLOGY}

This study follows four research steps for examining how $\mathrm{O} 2 \mathrm{O}$ marketing functions. First, based on the literature, we developed a questionnaire to measure $\mathrm{O} 2 \mathrm{O}$ marketing adoption behavior. Second, samples were collected using InsightXplorer's Web survey system. Third, the key factors for $\mathrm{O} 2 \mathrm{O}$ marketing adoption behavior were extracted using factor analysis. Fourth, we used a multinomial logit model to analyze search and purchasing behaviors offline, online, and on mobile channels. Fifth, the study compared the differences in search and purchasing behaviors between two products, computers and restaurant food. Sixth, the study measured the cross-channel consumer change channel factor. The research frame is presented in Figure 1. 


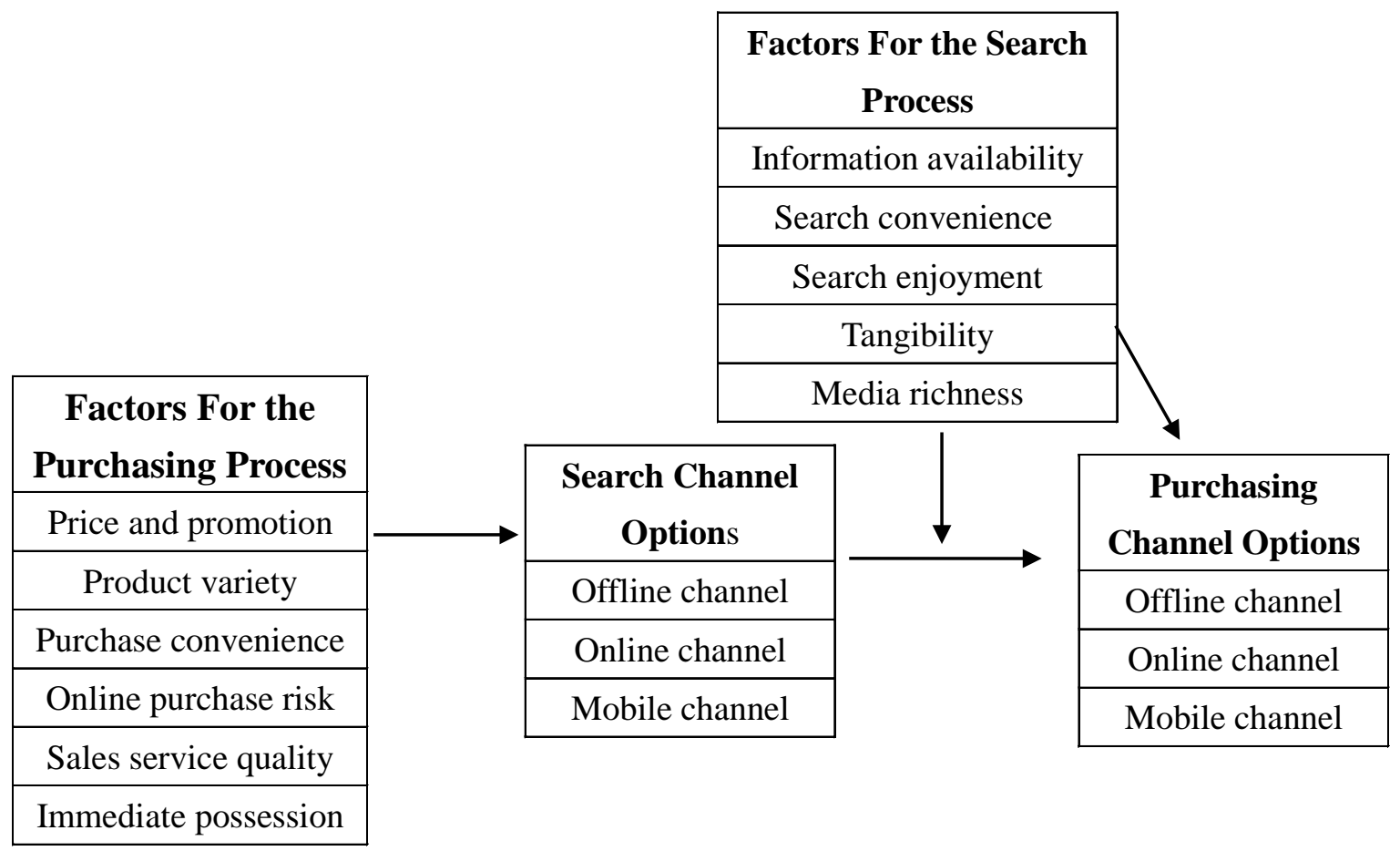

Figure 1 Research Frame

\section{Data Collection and Sample}

Based on the literature, we developed a questionnaire that comprises of 42 questions for measuring the key constructs of $\mathrm{O} 2 \mathrm{O}$ marketing, as shown in the questionnaire design of $\mathrm{O} 2 \mathrm{O}$ marketing constructs. InsightXplorer survey and CyberPanel systems were used to collect samples (InsightXplorer, 2014). In the Web survey, we first asked respondents the channel through which they usually search for or purchase products such as restaurant food. To ensure that the questionnaire was applicable to internet users, we used a structured sample with gender and age proportions representative of the internet population according to a report published by the Taiwan Network Information Center. We collected 689 samples in order to evaluate all facets with EFA analysis for the pretest. For the formal test, we conducted a CFA analysis based on the factors summarized in the EFA analysis to confirm that these items really belong to these factors. We received 1,256 valid responses from internet users in total. Among the respondents, 626 (49.8\%) were men and 630 (50.2\%) were women; 423 (24.9\%) were aged between 20 and 29 years; 423 (33.6\%) were aged between 30 and 39 years; 292 (23.2\%) were aged between 40 and 49 years; and 228 (18.2\%) were older than 50. 


\section{Questionnaire Design}

We conducted a pre-test and formal two-stage online questionnaire distribution through the InsightXplorer survey and CyberPanel systems. In the pre-test stage, pretest questionnaires were issued based on the literature reviewed and expert interviews which measure $\mathrm{O} 2 \mathrm{O}$ marketing model adoption behavior. The important factors to be considered are "factors for the search process" including information availability, search convenience, search enjoyment, tangibility, and media richness. There are a total of 18 metrics. The $\mathrm{O} 2 \mathrm{O}$ marketing model adopts behavioral "factors for the purchasing process" including price and promotion, product variety, purchase convenience, online purchase risk, sales service quality, and immediate possession, with a total of 25 indicators. The scale of the survey questionnaire is based on Likert's 6-point scale. The relationship between the adoption mode and the adoption behavior of the $\mathrm{O} 2 \mathrm{O}$ marketing model is measured. The scale is expressed in six levels (from 1 to 6 points, with 1 indicating strongly disagree and 6 indicating strongly agree) to avoid the centralizing tendency of the answers of the respondents.

This study focuses on consumers' decisions whether or not to use the internet and mobile networks to purchase products. In the collection of formal questionnaires, since the product category most commonly used in the $\mathrm{O} 2 \mathrm{O}$ marketing model is restaurant meal coupons, we asked consumers whether they had searched for and purchased meals through the internet in the past year. Then, we asked about the methods the respondents used for searching and the reasons why they used such methods. Finally, we asked the respondents about the methods available for them to buy restaurant-meal coupons and why they considered these methods.

\section{Reliability}

Cronbach's $\alpha$ was used to measure the reliability of the questionnaire. The Cronbach's $\alpha$ of each dimension is presented as follows: 0.90 for information availability, 0.89 for search convenience, 0.81 for media richness, 0.88 for enjoyment, 0.86 for tangibility, 0.83 for sales service quality, 0.84 for purchase convenience, 0.90 for online purchase risk, 0.83 for price and promotion, 0.80 for product variety, and 0.76 for immediate possession. All Cronbach's $\alpha$ values of our questionnaire were higher than 0.7, indicating high internal consistency.

\section{Factor Analysis}

In the formal stage, Smart PLS is used for reliability analysis and validity analysis, and Limdep 10 is used for the Multinomial Logit Model. The factors of O2O adoption behavior were extracted using EFA. The Kaiser-Meyer-Olkin measure of sampling 
adequacy was calculated $(\mathrm{KMO}=0.961)$, and Bartlett's test of sphericity verified that the items were related (chi squared $=22985.336$, d.f. $=1128$, Sig. $<0.05$ ). Therefore, factor analysis was suitable for this study.

The results of EFA revealed five factors as the search factors of $\mathrm{O} 2 \mathrm{O}$ marketing adoption behavior: information availability, search convenience, media richness, enjoyment, and tangibility. The measurement factor loading of these factors is between 0.606 to 0.887 . The number of total Variance Explained is $76.740 \%$. The results of EFA revealed six factors as the search factors of $\mathrm{O} 2 \mathrm{O}$ marketing adoption behavior: price and promotion, product variety, purchase convenience, online purchase risk, sales service quality, and immediate possession. The measurement factor loading of these factors is between 0.479 to 0.811 . The number of total Variance Explained is $70.406 \%$. These data show that the EFA analysis results are sufficient.

In agreement with Brunelle (2009), Shim, Eastlick, Lotz, and Warrington (2001), To, Liao \& Lin (2007), and Verhoef et al. (2007), our results confirm that these five factors are search factors. The results of EFA revealed six factors as the purchase factors of $\mathrm{O} 2 \mathrm{O}$ marketing adoption behavior: sales service quality, purchase convenience, online purchase risk, price and promotion, product variety, and immediate possession (Table 3). In agreement with Kleijnen, de Ruyter, and Wetzels (2007), Noble et al. (2005), and Verhoef et al. (2007), our results confirm that these six factors are purchase factors.

We also used confirmatory factor analysis (CFA) to test the reliability of the questionnaires. The overall Cronbach's $\alpha$ coefficient in the questionnaire analysis for this research was 0.777 . The Cronbach's $\alpha$ of all items exceeded 0.7 , which is an excellent level (Cooper \& Schindler, 2003). Validity analysis results for the 11 variables are listed as follows: information availability (composite reliability $[\mathrm{CR}]=0.89$, average variance extracted $[\mathrm{AVE}]=0.68)$, search convenience $(\mathrm{CR}=0.91, \mathrm{AVE}=0.79)$, media richness $(\mathrm{CR}=0.92$, AVE $=0.75)$, search enjoyment $(\mathrm{CR}=0.94, \mathrm{AVE}=0.81)$, tangibility $(\mathrm{CR}=0.96, \mathrm{AVE}=0.89)$, sales service quality $(\mathrm{CR}=0.71, \mathrm{AVE}=0.51)$, purchase convenience $(\mathrm{CR}=0.89, \mathrm{AVE}=0.68)$, online purchase risk $(\mathrm{CR}=0.91, \mathrm{AVE}$ $=0.62)$, price and promotion $(\mathrm{CR}=0.93, \mathrm{AVE}=0.76)$, product variety $(\mathrm{CR}=0.94$, AVE $=0.83$ ), and immediate possession ( $\mathrm{CR}=0.92$, AVE $=0.79)$. The completely standardized factor loading of all items exceeded 0.5, the CR surpassed 0.7 , and the AVE surpassed 0.5 (Fornell \& Larcker, 1981). 


\section{RESULTS AND ANALYSIS}

\section{Multinomial Logit Model}

\section{Search behavior}

Table 1 shows the results for search behavior. An analysis of search behavior (offline vs. online) revealed that information availability (coefficient $=0.532, \mathrm{Z}=3.310$, $\mathrm{p}<.01$ ) and search convenience (coefficient $=0.688, \mathrm{Z}=4.910, \mathrm{p}<.01$ ) significantly influence consumers to search online, and media richness (coefficient $=-0.330, Z=$ $-2.240, \mathrm{p}<.05$ ) and tangibility (coefficient $=-1.363, \mathrm{Z}=-12.000, \mathrm{p}<.01$ ) significantly influence consumers to search offline. A second analysis of search behavior (offline vs. mobile) revealed that search convenience (coefficient $=1.067, \mathrm{Z}=5.580, \mathrm{p}<.01$ ) significantly influences consumers to search using mobile devices, and tangibility (coefficient $=-1.177, \mathrm{Z}=-9.650, \mathrm{p}<.01$ ) significantly influences consumers to search offline. A third analysis of search behavior (online vs. mobile) revealed that search convenience (coefficient $=-0.490, \mathrm{Z}=-2.780, \mathrm{p}<.05$ ) and tangibility (coefficient $=$ $0.187, \mathrm{Z}=-2.410, \mathrm{p}<.05)$ significantly influence consumers to search using mobile devices, and information availability significantly influences consumers to search online.

The overall hypothesis test results regarding search behavior showed that consumers placing greater priority on information availability were more likely to search online; thus, H1 was verified. Consumers placing greater priority on search convenience were more likely to search using mobile devices; thus, H2 was verified. However, consumers prioritizing search enjoyment were not likely to use any search channel; hence, H3 was not verified. Still, consumers placing greater priority on media richness and tangibility were more likely to search offline; hence, H4 and H5 were verified. 
Table 1 Results for Search Behavior

\begin{tabular}{lllll}
\hline & Construct & Coefficient & Z value & $|\mathbf{z}|>\mathbf{Z}^{*}$ \\
\hline \multirow{5}{*}{ Offline VS Online } & Constant & $1.243^{*}$ & 2.180 & 0.029 \\
& Information availability. & $0.532^{* *}$ & 3.310 & 0.001 \\
& Search convenience. & $0.688^{* *}$ & 4.910 & 0.000 \\
& Search enjoyment. & 0.096 & 0.720 & 0.469 \\
& Media richness. & $-0.330^{*}$ & -2.240 & 0.025 \\
& Tangible & $-1.363^{* *}$ & -12.000 & 0.000 \\
& Constant & -0.363 & -0.470 & 0.638 \\
& Information availability. & 0.042 & 0.200 & 0.840 \\
& Search convenience. & $1.067^{* *}$ & 5.580 & 0.000 \\
& Search enjoyment. & 0.135 & 0.840 & 0.403 \\
& Media richness. & -0.300 & -1.730 & 0.083 \\
& Tangible & $-1.177^{* *}$ & -9.650 & 0.000 \\
& Constant & $-1.606^{*}$ & -2.190 & 0.028 \\
& Information availability. & $-0.490^{* *}$ & -2.780 & 0.006 \\
& Search convenience. & $0.379^{*}$ & 2.270 & 0.023 \\
Online VS Mobile & Search enjoyment. & 0.039 & 0.270 & 0.785 \\
& Media richness. & 0.030 & 0.210 & 0.831 \\
& Tangible & $0.187^{*}$ & 2.410 & 0.016 \\
\hline
\end{tabular}

\section{Purchase behavior}

Table 2 shows the results for purchase behavior. An analysis of purchase behavior (offline vs. online) revealed that product variety (coefficient $=0.426, \mathrm{Z}=$ 3.110, $\mathrm{p}<.01$ ), purchase convenience (coefficient $=0.374, \mathrm{Z}=3.270, \mathrm{p}<.01$ ), and price and promotion (coefficient $=0.923, \mathrm{Z}=7.450, \mathrm{p}<.01$ ) significantly influence consumers to purchase online and that sales service quality (coefficient $=-0.850, \mathrm{Z}=$ $-5.280, \mathrm{p}<.01$ ) and online purchase risk (coefficient $=-0.970, \mathrm{Z}=-7.640, \mathrm{p}<0.01$ ) influence consumers to purchase offline. A second analysis of purchase behavior (offline vs. mobile) revealed that sales service quality (coefficient $=-0.702, Z=-2.140$, $\mathrm{p}<.05$ ) and online purchase risk (coefficient $=-1.038, \mathrm{Z}=-5.820, \mathrm{p}<.01$ ) significantly influence consumers to purchase offline and that purchase convenience (coefficient $=0.686, \mathrm{Z}=2.840, \mathrm{p}<.01$ ) and price and promotion (coefficient $=0.780$, $\mathrm{Z}=2.780, \mathrm{p}<.01$ ) significantly influence consumers to purchase using mobile devices. A third analysis of purchase behavior (online vs. mobile) revealed that no factor significantly influenced consumers to purchase using any specific channel. 
The overall hypothesis test results regarding purchase behavior showed that consumers placing greater priority on sales service quality were more likely to purchase offline; thus, H6 was verified. Consumers placing greater priority on product variety were more likely to purchase online; thus, $\mathrm{H} 7$ was verified. Consumers placing greater priority on purchase convenience were more likely to purchase online and by using mobile devices; thus, H8 was partially verified. Consumers placing greater priority on online purchase risk were more likely to purchase offline, supporting H9. Consumers placing greater priority on price and promotion were more likely to purchase online and by using mobile devices, partially supporting H10. Finally, consumers prioritizing immediate possession were not likely to purchase using any channel; thus, H11 was not supported.

Table 2 Results for Purchasing Behavior

\begin{tabular}{|c|c|c|c|c|}
\hline & Construct & Coefficient & $\mathrm{Z}$ value & $|\mathbf{z}|>\mathbf{Z}^{*}$ \\
\hline \multirow{7}{*}{ Offline VS Online } & Constant & -0.603 & -1.010 & 0.311 \\
\hline & Sales service quality & $-0.850 * *$ & -5.280 & 0.000 \\
\hline & Product variety & $0.426 * *$ & 3.110 & 0.002 \\
\hline & Purchase convenience & $0.374 * *$ & 3.270 & 0.001 \\
\hline & Online purchase risk & $-0.970 * *$ & -7.640 & 0.000 \\
\hline & Price and promotion & $0.923 * *$ & 7.450 & 0.000 \\
\hline & Immediate possession & -0.014 & -0.080 & 0.932 \\
\hline \multirow{7}{*}{ Offline VS Mobile } & Constant & $-4.203^{* *}$ & -3.260 & 0.001 \\
\hline & Sales service quality & $-0.702 *$ & -2.140 & 0.032 \\
\hline & Product variety & -0.023 & -0.090 & 0.932 \\
\hline & Purchase convenience & $0.686^{* *}$ & 2.840 & 0.005 \\
\hline & Online purchase risk & $-1.038 * *$ & -5.820 & 0.000 \\
\hline & Price and promotion & $0.780 * *$ & 2.780 & 0.006 \\
\hline & Immediate possession & 0.488 & 1.470 & 0.141 \\
\hline \multirow{7}{*}{ Online VS Mobile } & Constant & $-3.600 * *$ & -2.680 & 0.007 \\
\hline & Sales service quality & 0.149 & 0.450 & 0.652 \\
\hline & Product variety & -0.449 & -1.610 & 0.107 \\
\hline & Purchase convenience & 0.312 & 1.250 & 0.210 \\
\hline & Online purchase risk & -0.068 & -0.400 & 0.689 \\
\hline & Price and promotion & -0.144 & -0.510 & 0.611 \\
\hline & Immediate possession & 0.502 & 1.490 & 0.137 \\
\hline
\end{tabular}

Table 3 shows the results of the multinomial logit model for restaurant search 
behavior. The first analysis of restaurant search behavior (offline vs. online) revealed that search convenience (coefficient $=0.651, \mathrm{Z}=3.310, \mathrm{p}<.01$ ) significantly influences consumers to search online, whereas tangibility (coefficient $=-0.914, Z=-9.060, p$ $<.01)$ significantly influences consumers to search offline. The second analysis of restaurant search behavior (offline vs. mobile) revealed that search convenience (coefficient $=1.045, \mathrm{Z}=4.580, \mathrm{p}<0.01$ ) significantly influences consumers to search using mobile devices, and tangibility (coefficient $=-0.830, \mathrm{Z}=-4.570, \mathrm{p}<.01$ ) significantly influences consumers to search offline. Finally, the third analysis of restaurant search behavior (online vs. mobile) revealed that search convenience (coefficient $=0.394, \mathrm{Z}=2.340, \mathrm{p}<0.01$ ) significantly influences consumers to search using mobile devices.

Table 3 Multinomial Logit Model Results for Restaurant Search Behavior

\begin{tabular}{llccc}
\hline & Construct & Coefficient & Z value & $|\mathbf{z}|>\mathbf{Z}^{*}$ \\
\hline \multirow{5}{*}{ Offline VS Online } & Constant & $1.752^{*}$ & 2.100 & 0.036 \\
& Information availability & 0.231 & 1.150 & 0.252 \\
& Search convenience. & $0.651^{* *}$ & 3.310 & 0.001 \\
& Search enjoyment. & -0.086 & -0.450 & 0.655 \\
& Media richness. & -0.235 & -1.180 & 0.238 \\
& Tangible & $-0.914^{* *}$ & -9.060 & 0.000 \\
& Constant & -0.419 & -0.420 & 0.671 \\
& Information availability & 0.047 & 0.200 & 0.843 \\
& Search convenience. & $1.045^{* *}$ & 4.580 & 0.000 \\
& Search enjoyment. & -0.149 & -0.660 & 0.508 \\
& Media richness. & -0.142 & -0.640 & 0.521 \\
& Tangible. & $-0.830^{* *}$ & -4.570 & 0.000 \\
& Constant & $-2.170^{* *}$ & -2.710 & 0.007 \\
& Information availability & -0.184 & -1.020 & 0.307 \\
& Search convenience. & $0.394^{*}$ & 2.340 & 0.020 \\
Online VS Mobile & Search enjoyment. & -0.064 & -0.380 & 0.703 \\
& Media richness. & 0.094 & 0.570 & 0.569 \\
& Tangible & 0.084 & 0.740 & 0.461 \\
\hline
\end{tabular}

Table 4 shows the first analysis of restaurant purchase behavior (offline vs. online) revealed that product variety, purchase convenience, and price and promotion significantly influence consumers to purchase online. However, sales service quality 
and online purchase risk significantly influence consumers to purchase offline. The second analysis of restaurant purchase behavior (offline vs. mobile) revealed that price and promotion and immediate possession significantly influence consumers to purchase using mobile devices. Moreover, consumers placing greater priority on online purchase risk are more likely to purchase offline. The final analysis comparing online and mobile channels revealed that consumers do not consider any factor for purchasing using any channel.

Table 4 Results for Personal Computer Purchasing Behavior

\begin{tabular}{|c|c|c|c|c|}
\hline & Construct & Coefficient & $Z$ value & $|\mathbf{z}|>\mathbf{Z}^{*}$ \\
\hline \multirow{7}{*}{ Offline VS Online } & constant & -1.384 & -1.480 & 0.139 \\
\hline & sales service quality & $-1.077 * *$ & -4.260 & 0.000 \\
\hline & product variety & $0.467 * *$ & 2.750 & 0.006 \\
\hline & purchase convenience & $0.417^{*}$ & 2.230 & 0.026 \\
\hline & online purchase risk & $-1.075^{* *}$ & -5.570 & 0.000 \\
\hline & price and promotion & $0.823 * *$ & 4.460 & 0.000 \\
\hline & immediate possession & 0.407 & 1.750 & 0.079 \\
\hline \multirow{7}{*}{ Offline VS Mobile } & constant & $-4.293 * *$ & -3.250 & -3.250 \\
\hline & sales service quality & -0.260 & -0.500 & 0.620 \\
\hline & product variety & 0.016 & 0.040 & 0.964 \\
\hline & purchase convenience & 0.153 & 0.390 & 0.693 \\
\hline & online purchase risk & $-1.148 * *$ & -4.370 & 0.000 \\
\hline & price and promotion & $0.752^{*}$ & 2.190 & 0.028 \\
\hline & immediate possession & $0.793^{*}$ & 1.980 & 0.048 \\
\hline \multirow{7}{*}{ Online VS Mobile } & constant & $-2.908 *$ & -1.970 & 0.049 \\
\hline & sales service quality & 0.817 & 1.550 & 0.122 \\
\hline & product variety & -0.452 & -1.290 & 0.196 \\
\hline & purchase convenience & -0.264 & -0.670 & 0.501 \\
\hline & online purchase risk & -0.073 & -0.290 & 0.771 \\
\hline & price and promotion & -0.070 & -0.210 & 0.837 \\
\hline & immediate possession & 0.386 & 0.950 & 0.340 \\
\hline
\end{tabular}

\section{Cross-channel versus no cross-channel purchasing}

An analysis of restaurant offline cross-channel behavior (offline-offline vs. offline-online; Table 5) revealed that sales service quality and online purchase risk do not significantly influence consumers to cross channels to purchase products, so H12 
and H15 were not verified. Purchase convenience does significantly influence consumers to not cross channels to purchase products offline.

\begin{tabular}{llll} 
Table 5 & Results for Offline-Offline vs Offline-Online \\
\hline Construct & Coefficient & Z value & $|\mathbf{z}| \mathbf{Z}^{*}$ \\
\hline Constant & -2.806 & -1.470 & 0.142 \\
Sales Service Quality & -0.408 & -0.720 & 0.472 \\
Product Variety & 0.355 & 1.190 & 0.234 \\
Purchase Convenience & $-0.798^{*}$ & -2.290 & 0.022 \\
Online Purchase Risk & -0.212 & -0.520 & 0.600 \\
Price and Promotion & 0.646 & 1.250 & 0.213 \\
Immediate possession & 0.183 & 0.370 & 0.711 \\
\hline
\end{tabular}

In an analysis of restaurant online cross-channel behavior (online-online vs. online-offline; Table 6), price and promotion was the major factor that significantly influenced consumers to not cross channels. As such, H13 was not verified.

Table 6 Results for Online-Online vs Online-Offline

\begin{tabular}{lccc}
\hline Construct & Coefficient & $\mathbf{Z}$ value & $|\mathbf{z}|>\mathbf{Z}^{*}$ \\
\hline Constant & $1.500^{*}$ & 2.130 & 0.034 \\
Sales service quality & 0.333 & 1.770 & 0.076 \\
Product variety & -0.246 & -1.800 & 0.072 \\
Purchase convenience & -0.216 & -1.460 & 0.146 \\
Online purchase risk & 0.106 & 0.840 & 0.399 \\
Price and promotion & $-0.475^{* *}$ & -3.700 & 0.000 \\
Immediate possession & 0.008 & 0.050 & 0.960 \\
\hline
\end{tabular}

An analysis of restaurant mobile cross-channel behavior (mobile-mobile vs. mobile-offline) revealed that price and promotion significantly influence consumers not to cross channels to purchase products (Table 7). As such, H14 and H17 were not verified. 
Table 7 Results for Mobile-Mobile vs Mobile-Offline

\begin{tabular}{lccc}
\hline Construct & Coefficient & $\mathbf{Z}$ value & $|\mathbf{z}|>\mathbf{Z}^{*}$ \\
\hline Constant & -1.261 & -1.590 & 0.112 \\
Sales service quality & 0.352 & 1.790 & 0.074 \\
Product variety & 0.011 & 0.060 & 0.951 \\
Purchase convenience & -0.028 & -0.160 & 0.875 \\
Online purchase risk & 0.223 & 1.310 & 0.190 \\
Price and Promotion & $-0.338^{*}$ & -2.090 & 0.037 \\
Immediate possession & -0.284 & -1.430 & 0.154 \\
\hline
\end{tabular}

\section{CONCLUSION AND IMPLICATIONS}

O2O marketing is a widely discussed topic among marketers. Based on the literature reviewed, we developed measures for adopting the $\mathrm{O} 2 \mathrm{O}$ marketing model. Using EFA and confirmatory factor analysis, we extracted five factors (information availability, search convenience, media richness, enjoyment, and tangibility) that determined consumer search behavior and six factors (sales service quality, purchase convenience, online purchase risk, price and promotion, product variety, and immediate possession) that determined consumer purchase behavior in offline and online channels.

We then used a multinomial logit model to examine the relationships among the channel adoption factors, search channels, and purchase channels. In the offline channel, the results regarding media richness, tangibility, sales service quality, and online purchase risk supported our theoretical derivation (Jiang \& Balasubramanian, 2014; Maity \& Dass, 2014; Shin, 2007). Hence, O2O retailers must enhance sales of their products intelligently, enable e-consumers to access detailed product information, and improve services (e.g., quick return of goods) in the offline channel. In the online channel, only the results regarding price and promotion supported the theoretical derivation. Therefore, $\mathrm{O} 2 \mathrm{O}$ retailers must provide more products, offer functions for easily comparing products, prices, and promotions, shorten the purchasing process, and continue to provide promotional information in the online channel. In the mobile channel, the results regarding search convenience, purchase convenience, and price and promotion supported our theoretical derivation (Lee, Han, Hwang, \& Ahn, 2013). Hence, O2O marketers must shorten the search and purchase processes, enable consumers to quickly purchase products in the shopping process, and provide locationbased service promotions to attract consumers.

Regarding cross-channel behavior, when consumers focus on price and promotion information, they have an increased tendency to search for products through online and 
mobile channels. Moreover, payment through the offline channel enables discovering whether consumers are concerned about the aforementioned factors; as such consumers consequently had a tendency to buy discount coupons. As could be seen via the online and mobile channels, performance in this regard is preferred; in this case, the distributor should continue to maintain this advantage. We also found that for consumers, purchasing a restaurant ticket is more convenient offline; the online and mobile channel payment processes are not efficient. Therefore, online and mobile channel restaurant ticket purchasing processes should be improved to enable consumers to quickly order products. If consumers focus on service quality, then online channel consumers might cross to the offline channel to purchase tickets. We propose that service efficiency and service attitudes be improved in the offline channel.

Finally, we confirmed the relationship between channel adoption behavior and channel adoption factors in the search and purchase processes. Marketers could study our findings to learn how to apply resources to these three channels to develop a more effective $\mathrm{O} 2 \mathrm{O}$ marketing strategy and provide efficient transaction procedures by integrating the online and offline channels. This understanding could facilitate the development of marketing plans. The various channels and stimuli that facilitate attracting consumers to search for and purchase goods must be considered. However, because only Taiwanese users were included in this study, the results may apply only to Taiwan. Future studies could focus on comprehensive perspectives by clarifying regional and cultural influences. Furthermore, this study used restaurants as the main research product. Future research could examine other product types, such as computers, transportation tickets, or clothes. Moreover, future studies could incorporate other explanatory variables.

\section{REFERENCES}

Alba, J., Lynch, J., Weitz, B., Janiszewski, C., Lutz, R., Sawyer, A., \& Wood, S. (1997). Interactive home shopping: consumer, retailer, and manufacturer incentives to participate in electronic marketplaces. The Journal of Marketing, 4(3), 38-53.

http://dx.doi.org/10. 2307/1251788

Bakos, J. Y. (1997). Reducing buyer search costs: implications for electronic marketplaces. Management Science, 43(12), 1676-1692. http://dx.doi.org/10.1287/mnsc.43.12.1676

Balasubramanian, S. (1998). Mail versus mall: A strategic analysis of competition between direct marketers and conventional retailers. Marketing Science, 17(3), 181-195.

http://dx.doi.org/10.1287/mksc.17.3.181

Bang, Y., Lee, D.-J., Han, K., Hwang, M., \& Ahn, J.-H. (2013). Channel capabilities, product 
characteristics, and the impacts of mobile channel introduction. Journal of Management Information Systems, 30(2), 101-126. http://dx.doi.org/10.2753/MIS0742-1222300204

Brunelle, E. (2009). Introducing media richness into an integrated model of consumers' intentions to use online stores in their purchase process. Journal of Internet Commerce, 8(3-4), 222-245. http://dx.doi.org/10.1080/15332860903467649

Business Insider (2011). Ron Conway's confidential investment "Megatrend" -- O2O Commerce. Retrieved from http://www.businessinsider.com/ron-conway-megatrend-2011-2\#ixzz2oSi1LA54

Chen, X., Wang, X., \& Jiang, X. (2016). The impact of power structure on the retail service supply chain with an $\mathrm{O} 2 \mathrm{O}$ mixed channel. The Journal of the Operational Research Society, 67(2), 294-301. http://dx.doi.org/10.1057/jors.2015.6

Chiang, W.-y. K., Zhang, D., \& Zhou, L. (2006). Predicting and explaining patronage behavior toward web and traditional stores using neural networks: A comparative analysis with logistic regression. Decision Support Systems, 41(2), 514-531.

http://dx.doi.org/ 10.1016 /j.dss.2004.08.016

Chocarro, R., Cortiñas, M., \& Villanueva, M.-L. (2013). Situational variables in online versus offline channel choice. Electronic Commerce Research and Applications. 12(5), 347-361. http://dx.doi.org/10.1016/j.elerap.2013.03.004

Clemes, M. D., Gan, C., \& Zhang, J. (2013). An empirical analysis of online shopping adoption in Beijing, China. Journal of Retailing and Consumer Services. 21(3), 364-375. http://dx.doi.org/10.1016/j.jretconser.2013.08.003

ComScore, (2013) Consumers want choices and convenience when shopping online. Retrieved from http://www.comscore.com/Insights/Press-Releases/2013/6/Consumers-WantChoices-and-Convenience-When-Shopping-Online

Cooper, D.R. \& Schindler, P.S. (2003). Business Research Methods (8th edn) McGraw-Hil New York.

Cox, D. F. \& Rich, S. U. (1964). Perceived risk and consumer decision-making: The case of telephone shopping. Journal of Marketing Research, 1(4), 32-39. http://dx.doi.org/10. 2307/3150375

Crespo, A. H. \& del Bosque, I. R. (2010). The influence of the commercial features of the Internet on the adoption of e-commerce by consumers. Electronic Commerce Research and Applications, 9(6), 562-575. https://doi.org/10.1016/j.elerap.2010.04.006

eMarketer (2018). O2O measurement and marketing 2018: How location tracking, identity graphs and in-store metrics are improving Online-to-Offline capabilities. Retrieved from https://www.emarketer.com/content/o2o-measurement-and-marketing-2018

Evanschitzky, H., Iyer, G. R., Hesse, J., \& Ahlert, D. (2004). E-satisfaction: A re-examination. Journal of Retailing, 80(3), 239-247. http://dx.doi.org/10.1016/j.jretai.2004.08.002 
Farag, S., Schwanen, T., Dijst, M. and Faber, J. (2007). Shopping online and/or in-store? A structural equation model of the relationships between e-shopping and in-store shopping. Transportation Research Part A, 41, 125-141.

http://dx.doi.org/10.1016/j.tra.2006.02. 003

Featherman, M. S., \& Pavlou, P. A. (2003). Predicting e-services adoption: A perceived risk facets perspective. International Journal of Human-Computer Studies, 59(4), 451-474. http://dx.doi.org/10.1016/S1071-5819(03)00111-3

Forsythe, S., Liu, C., Shannon, D., \& Gardner, L. C. (2006). Development of a scale to measure the perceived benefits and risks of online shopping. Journal of Interactive Marketing, 20(2), 55-75. http://dx.doi.org/10.1002/dir.20061

Gupta, A., Su, B.-C., \& Walter, Z. (2004). An empirical study of consumer switching from traditional to electronic channels: A purchase-decision process perspective. International Journal of Electronic Commerce, 8(3), 131-161. http://dx.doi.org/10.1080/ 10864415.2004.11044302

InsightXplorer (Nov. 13, 2014). What' IX survey?. Retrieved from http://www. insightxplorer.com/product/ixsurvey01.html

Jiang, P. \& Balasubramanian, S. K. (2014). An empirical comparison of market efficiency: Electronic marketplaces vs. traditional retail formats. Electronic Commerce Research and Applications, 13(2), 98-109. http://dx.doi.org/10.1016/j.elerap.2013.11.003

Shin, J. (2007). How does free riding on consumer service affect competition? Marketing Science, 26(4), 488-503. http://doi 10.1287/mksc.1060.0252

Jones, M. A. (1999). Entertaining shopping experiences: An exploratory investigation. Journal of Retailing and Consumer Services, 6(3), 129-139. http://dx.doi.org/10.1016/S0969-6989(98)00028-9

Keeney, R. L. (1999). The value of Internet commerce to the consumer. Management Science, 45(4), 533-542. https://doi.org/10.1287/mnsc.45.4.533

Kleijnen, M., De Ruyter, K., \& Wetzels, M. (2007). An assessment of value creation in mobile service delivery and the moderating role of time consciousness. Journal of Retailing, 83(1), 33-46. http://dx.doi.org/10.1016/j.jretai.2006.10.004

Konuş, U., Verhoef, P. C., \& Neslin, S. A. (2008). Multichannel shopper segments and their covariates. Journal of Retailing, 84(4), 398-413.

http://dx.doi.org/10.1016/j.jretai. 2008.09.002

Kwon, K.-N. \& Jain, D. (2009). Multichannel shopping through nontraditional retail formats: Variety-seeking behavior with hedonic and utilitarian motivations. Journal of Marketing Channels, 16(2), 149-168. http://dx.doi.org/10.1080/10466690802477418

Levin, A. M., Levin, I. P., \& Weller, J. A. (2005). A multi-attribute analysis of preferences for 
online and offline shopping: Differences across products, consumers, and shopping stages. Journal of Electronic Commerce Research, 6(4), 281-290.

Liu, C. \& Forsythe, S. (2011). Examining drivers of online purchase intensity: Moderating role of adoption duration in sustaining post-adoption online shopping. Journal of Retailing and Consumer Services, 18(1), 101-109. http://dx.doi.org/10.1016/j.jretconser.2010. 10.004

Maity, M. \& Dass, M. (2014). Consumer decision-making across modern and traditional channels: E-Commerce, m-commerce, in-store. Decision Support Systems, 61, 34-46. http://doi.org/10.1016/j.dss.2014.01.008

Noble, S. M., Griffith, D. A., \& Weinberger, M. G. (2005). Consumer derived utilitarian value and channel utilization in a multi-channel retail context. Journal of Business Research, 58(12), 1643-1651. http://dx.doi.org/10.1016/j.jbusres.2004.10.005

Nielsen (Nov. 13, 2014). Nielsen Internet shopping behavior research. Retrieved from http://www.nielsen.com/content/dam/nielsenglobal/tw/docs/online-shopper-report2014ch.pdf

Parasuraman, A., Zeithaml, V. A., \& Berry, L. L. (1988). SERVQUAL: A multiple-item scale for measuring consumer perceptions of service quality. Journal of Retailing, 64(1), 12-40.

Parasuraman, A., Zeithaml, V. A., \& Malhotra, A. (2005). ES-QUAL: A multiple-item scale for assessing electronic sell service quality. Journal of Service Research, 7(3), 213-233. https://doi.org/10.1177/1094670504271156

Reibstein, D. J. (2002). What attracts consumers to online stores, and what keeps them coming back? Journal of the Academy of Marketing Science, 30(4), 465-473. https://doi.org /10.1177/009207002236918

Rohm, A. J., \& Swaminathan, V. (2004). A typology of online shoppers based on shopping motivations. Journal of Business Research, 57(7), 748-757. http://dx.doi.org/10.1016 /S0148-2963(02)00351-X

Pookulangara, S., Hawley, J., \& Xiao, G. (2011), Explaining consumers’ channel-switching behavior using the theory of planned behavior. Journal of Retailing and Consumer Services, 18(4), 311-321.

Schröder, H., \& Zaharia, S. (2008). Linking multi-channel consumer behavior with shopping motives: An empirical investigation of a German retailer. Journal of Retailing and Consumer Services, 15(6), 452-468.

Shim, S., Eastlick, M. A., Lotz, S. L., \& Warrington, P. (2001). An online prepurchase intentions model: The role of intention to search. Journal of Retailing, 77(3), 397-416. http://dx.doi.org/10.1016/S0022-4359(01)00051-3

Taylor, J. W. (1974). The role of risk in consumer behavior. Journal of Marketing, 38(2), 5460. http://dx.doi.org/10.2307/1250198

TechCrunch (2010). Why Online2Offline commerce is a trillion dollar opportunity. Retrieved 
from http://techcrunch.com/2010/08/07/why-online2offline-commerce-is-a-trilliondollar-opportunity/

The Online Economy (2012). O2O: O2 for local commerce? Retrieved from

http://www.onlineeconomy.org/tag/o2o

TNS (2013). Mobile has been cast as the villain in retailers' showrooming nightmares - But the latest mobile life study suggests it could yet be one solution to their problems. Retrieved from http://www.tnsglobal.com/sites/default/files/whitepaper/TNS_Blessing_in_disguise.pdf

To, P., Liao, C. \& Lin, T. (2007) Shopping motivations on internet: A study based on utilitarian and hedonic value. Technovation, 27, 774-787. http://dx.doi.org/10.1016/j.technovation. 2007.01.001

Van Baal, S. \& Dach, C. (2005). Free riding and consumer retention across retailers' channels. Journal of Interactive Marketing, 19(2), 75-85. http://doi.org/10.1002/dir.20036

Verhoef, P. C., Neslin, S. A., \& Vroomen, B. (2007). Multichannel consumer management: Understanding the research-shopper phenomenon. International Journal of Research in Marketing, 24(2), 129-148. https://doi.org/10.1016/j.ijresmar.2006.11.002

Wolfinbarger, M. F. \& Gilly, M. C. (2001) Shopping online for freedom, control and fun. California Management Review, 43(2), 34-55. http://doi.org/10.2307/41166074

Yu, U.-J., Niehm, L. S., \& Russell, D. W. (2011). Exploring perceived channel price, quality, and value as antecedents of channel choice and usage in multichannel shopping. Journal of Marketing Channels, 18(2), 79-102. http://doi.org/10.1080/1046669X.2011.558826 